\title{
Causes of Child Marriage and Its Effects on the Child in Jigawa State, North West Nigeria: Implications for Counselling
}

\author{
Assoc. Prof (Mrs) Anna Onoyase \\ Correspondence: Assoc. Prof (Mrs) Anna Onoyase, Department of Guidance and Counselling, Delta State University, \\ P.M.B. 1, Abraka, Delta State Nigeria. E-mail: tinaonoyase@gmail.com
}

Received: January 13, 2020

doi:10.11114/jets.v8i4.4724

\author{
Accepted: February 11, 2020 \\ Online Published: February 18, 2020 \\ URL: https://doi.org/10.11114/jets.v8i4.4724
}

\begin{abstract}
This research sought to find out the causes of child marriage and its effects on the child in Jigawa State, North-West Nigeria. In order to carry out this investigation, the researcher formulated two research questions and one hypothesis to guide the investigation. An instrument tagged "Causes Of Child Marriage And Its Effects On The Child" (COCMAIETCQ) was constructed by the investigator to collect information from the respondents. The instrument has 21 items, 10 on the causes of child marriage and 11 on effects of child marriage. The researcher conducted a reliability test on the instrument using split - half method to get a reliability coefficient of 0.79 . The researcher used the purposive sampling technique to select 270 married men and women that took part in the research. The investigator used 3 research assistants to administer 270 copies of the questionnaire on the respondents in the urban, semi - urban and rural areas of Jigawa State. The research assistants retrieved 72, 88 and 71 copies of the questionnaire from the respondents in urban, semi - urban and rural areas respectively. The researcher collated the data from the field work, used the mean and standard deviation to answer the research questions while one - way Analysis of Variance (ANOVA) was used to test the hypothesis at 0.05 level of significance. The investigator used 2.50 as benchmark to know if respondents agreed or disagreed with each of the 21 items of the instrument. The investigation revealed that there is child marriage due to poverty of parents with mean score of 3.18, Islamic religion allows child marriage with mean score of 2.90 , and high bride price encourages child marriage with mean score of 2.65. The research equally revealed that young married girls may develop obstetric fistula due to prolonged delivery with mean score of 3.22, early marriage of girls could lead to their drop - out from school with mean score of 3.19 and child marriage violates women's right to consensual marriage with mean score of 2.99. One of the recommendations was that the Jigawa State government should enact a law that prohibits child marriage so that women's rights to freedom of education are not violated.
\end{abstract}

Keywords: causes, child, marriage and effects

\section{Introduction}

Child marriage is the informal or formal marriage that the child entered into when he or she is not up to 18 years of age. In support of this, the United Nations International Children's Emergency Fund (2014) stated that, child marriage is a formal or an informal union entered into by an individual before reaching a certain age, specified by several global organisations as minors under the age of 18 . In most cases, one of the two people involved in the marriage is a child, and in numerous instances, it is the girl. Nour (2009), stated that in certain countries, even when the legal marriage age is 18 , cultural traditions take priority over legislative law. UNICEF (2012), stated that the countries with the highest rate of child marriage before the age of 18 are Niger, Chad, Mali, Bangladesh, Guinea and the Central African Republic. UNICEF (2012), also stated that child marriage violates the rights of children, it affects both boys and girls, but it is more common among girls.

\section{Review of Related Literature}

The issue of child marriage appears to be a global one and the causes may be numerous. According to UNFPA, the causes of child marriage include poverty and economic survival strategies, gender inequality, control over sexuality and protecting family honour, tradition and culture, insecurity particularly during war, famine or epidemics and family ties in which marriage is a means of consolidating powerful relations between families. Eradicating child marriage in Africa (2015), stated that child marriage is brought about as a result of poverty, bride price, dowry, cultural tradition laws that 
allow child marriages, religion, regional customs, fear of remaining unmarried, illiteracy and perceived inability of women to work for money.

\section{Causes of Child Marriage}

\section{Poverty}

One of the causes of child marriage may be poverty on the part of parents. Some of the parents view their daughters as economic burden and therefore take to early marriage of the child especially girls as a relief, not only to the family alone but also to the girl. Probably, this was why Nour (2009) and Asad (2013) asserted that some families view child marriage as a means to ensure their daughter's financial security and reduce the economic burden of the child on the family.

\section{Fear of Not being a Virgin}

Another cause of child marriage may be fear, for instance, a girl of above 18 years who is not married may be a victim of rape, which may be traumatic to the girl. Rai (2010), opined that such girls may not be seen as eligible for marriage if they are not virgins. In USA Today.com (2009), the fear is that an unmarried girl may engage in illicit relationships, or elope causing a permanent social blemish to her siblings, or that the impoverished family may be unable to find bachelors for grown- up girls in their economic social group.

\section{Protection From Sexual Promiscuity}

Child marriage may be brought about as a way of protecting the girl from sexual promiscuity. For instance, Nour (2006) opined that parents feel that child marriage provide their daughters with a sense of protection from sexual promiscuity and safe from sexually transmitted infections.

\section{Religion}

Child marriage may be due to the person's faith or religion. For instance, in Islam, no minimum age is set for marriage, but the age of marriage should coincide with puberty. This is why the classical Islamic law (Sharia), does not set a definite age for marriage but marriage can occur with puberty. However, UNICEF (2012), reports that the top five nations in the world with highest child marriage rates are: Niger 75\%, Chad 72\%, Mali 71\%, Bangladesh 64\% and Guinea 63\%. The five countries are Islamic majority. However, from Saudi Arabia's marriage reforms in 2009, it was observed that "although girls can marry even before reaching puberty, they cannot terminate the wedding contracts according to the Hanbali legal school, one of four major schools in Sunni Islam, which has complete control over female to male guardian".

\section{Bride Price}

The bride price is the money paid by a man marrying a girl to the parents of the girl in order to get their consent. Bearak (2006), and Nour (2006), opined that in some countries, the younger the bride, the higher the pride price she may fetch. This practice according to Soraya (2006), Boyden (2012), and Showdhurry (2004) creates an economic incentive where girls are sought and married early by her family to the highest bidder.

\section{Economic Security}

Gaffney-Rhys (2011), has opined that child marriage can also be seen as a means of ensuring a girl's economic security particularly if she lacks family members to provide for her.

\section{Effects}

\section{Health}

Nour (2006), has stressed that child marriage has great effects on the health of the girl. These health effects are due to the girls' physical immaturity where the pelvis and birth canal are not fully developed. Teen pregnancy, particularly below age 15 increases risk of developing obstetric fistula, since their smaller pelvises make them prone to obstructed labour. Nour further opined that girls who give birth before the age of 15 have an $88 \%$ risk of developing fistula. Furthermore, such girls who married at the age of 15 face the risk of sexuality transmitted diseases such as cervical cancer.

\section{Illiteracy}

Child marriage is known to affect the girl's education by putting an end to her education. Lee, Malhotra, Warner, and Glinski (2012) have opined that early marriage impedes a girl's ability to continue with her education as most drop out of school following marriage.

\section{Poverty}

Child marriage may result to poverty, probably, that was why Q \& A (2013), maintained that girls who are not educated may have limited opportunity to work and earn an income and financially provide for themselves. Q and A, asserted that this make girls more vulnerable to persistent poverty, most especially if their spouses die, abandon or divorce them. Gaffney-Rhys (2011), opined that girls in child marriage are often significantly younger than their husbands, they become 
widowed earlier in life and may face associated economic and social challenges for a greater portion of their life than a woman who marry later.

\section{Domestic Violence}

Teen marriage may be prone to domestic violence. Anita, Niranjan, Danieile, Donta and Jay (2010) opined, that girls who marry as children face severe and life threatening marital violence at higher rates. This was supported by Gaffney-Rhys (2011), when she said that, husbands in child marriage are often more than ten years older than their wives. This can increase the power and control a husband has over his wife and contribute to prevalence of spousal abuse.

\section{Development}

Child marriage has great effect on the economic development of countries where it is practiced. This is supported by Lee, Malhotra, Warner and Glinsks (2012) when they stressed that early marriage affect the girls' education which in turn affect her labour market participation.

\section{Women's Rights}

Child marriage tends to violate women's rights such as equality on the ground of sex and age to get health, free from slavery, equal access to education, freedom from violence, reproductive rights and rights to consensual marriage (UNICE, 2014).

\section{Operational Definition of Terms}

Child Marriage: Refers to the marriage of a girl under 18 years of age.

Urban: In this investigation, urban refers to the state capital and other towns with modern social amenities such as hospitals, electricity, pipeborne water, postal services, internet services, banks, airports, trunk A roads and higher institutions such as universities, polytechnics, and colleges of education.

Semi-Urban: Refers to towns with few modern social amenities like hospitals, trunk B roads, secondary schools, primary schools, banks, police posts, pipe borne water and post office.

Rural: These are few towns and villages with limited modern amenities like truck C roads, maternity, secondary and primary schools, boreholes and rural electricity board.

\section{Statement of the Problem}

Marriage is a life-long relationship that involves two people that are ready to live together the rest of their lives. In marriage, the man ought to seek the consent of the girl who is matured to decide for herself and determine whether she would be able to stay with the man the rest of her life. In child marriage, the question that comes to mind is whether a child is matured to decide for herself?

The problem of the research put in question form is that, "can a child take decision for herself, about the man she wants to marry? If she cannot, what are the causes of child marriage and what are the effects of child marriage? Specifically, the investigation sought to answer the following research questions:

1. What are the causes of child marriage?

2. What are the effects of child marriage on the child?

\section{Hypothesis}

1. There is no significant difference among the respondents in the urban, semi - urban and rural areas in their assessment of the effects of child marriage on the child.

\section{Research Method and Procedure}

The survey method has been used for this research. Shaibu (2012: 36), maintained that surveys can be conducted through the mail, with telephone interviews or with in-person interviews. In conducting this research, an instrument tagged, "Causes Of Child Marriage and Its Effects On The Child (COCMAIEOTCQ) was constructed by the researcher to collect information from the respondents. The instrument was made of 21 items, 10 on the causes of child marriage and 11 on the effects of child marriage. The subjects of the research were made to indicate their opinions if they agreed or disagreed with each of the items in the questionnaire by ticking $(\sqrt{ })$ strongly agreed $(\mathrm{SA})=4$, agreed $(\mathrm{A})=3$, disagreed $(\mathrm{D})=2$ and strongly disagreed $(\mathrm{SD})=1$. A reliability test conducted on the instrument using split - half method showed a reliability coefficient of 0.79 . The instrument had content and face validity. The language of drafting the instrument was considered appropriate.

The population of the research was made up of all married men and women in Jigawa State, North-West, Nigeria. This state is predominantly moslem. The investigator used purposive sampling method to select 270 married men and women 
that participated in the investigation. The researcher used 3 research assistants to administer 270 copies of the questionnaire on the respondents in the urban, semi - urban and rural areas of Jigawa State. The research assistants retrieved 72, 88 and 71 copies of the questionnaire from the respondents in the urban, semi - urban and rural areas respectively. Total number of retrieved questionnaire were 231 while un-retrieved were 39.

The information collected from fieldwork were collated by the investigator, the researcher used the mean and standard deviation to get the research questions answered and One - Way Analysis of Variance ANOVA was used to test the hypothesis. The researcher used 2.50 as benchmark to determine whether respondents agreed or disagreed with each of the 21 items contained in the questionnaire. The hypothesis was tested at 0.05 level of significance.

\section{Findings}

Research Question One: What are the causes of child marriage?

Table 1. Mean scores and standard deviation analysis on causes of child marriage, $\mathrm{N}=231$

\begin{tabular}{l|l|l|l|l}
\hline $\mathbf{S} / \mathbf{N}$ & Causes of child marriage & Mean & SD & Decision \\
\hline 1 & Poverty of parents & 3.18 & .92 & Agreed \\
\hline 2 & Fear of not being a virgin & 2.74 & 1.10 & Agreed \\
\hline 3 & Protection from sexual promiscuity & 2.81 & 1.05 & Agreed \\
\hline 4 & To promote political relationship & 1.85 & .92 & Disagreed \\
\hline 5 & Islamic religion allows child marriage & 2.90 & 1.01 & Agreed \\
\hline 6 & Christian religion allows child marriage & 1.77 & 1.05 & Disagreed \\
\hline 7 & High bride price encourages child marriage & 2.65 & .97 & Agreed \\
\hline 8 & Nigeria constitution allows child marriage & 1.83 & 1.04 & Disagreed \\
\hline 9 & Economic security & 2.64 & .99 & Agreed \\
\hline 10 & To prevent the girl from unwanted pregnancy & 2.99 & 1.02 & Agreed \\
\hline
\end{tabular}

The research has revealed in table one that poverty of parents was a cause of child marriage. This is because the mean score of 3.18 is greater than the benchmark of 2.50. Other causes of child marriage are, fear of not being a virgin with mean score of 2.74, protection from sexual promiscuity with mean score of 2.81, and Islamic religion that allows child marriage with mean score of 2.90. High bride price with mean score of 2.65 was shown to be a cause of child marriage, economic security with a mean score of 2.64 was found to be a cause of child marriage and to prevent the girl from unwanted pregnancy, with a mean score of 2.99 was revealed as cause of child marriage. All the mean scores already mentioned are higher than the benchmark of 2.50. The investigation has revealed in table one that, to promote political relationship with a mean score of 1.85 was not a cause of child marriage, Nigeria constitution with a mean score of 1.83 was not a cause of child marriage and Christian religion with a mean score of 1.77 was not found to be a cause of child marriage. This was because the mean scores of 1.85, 1.83 and 1.77 were below the benchmark of 2.50 in table one.

Research Question Two: What are the effects of child marriage? 
Table 2. Mean and standard deviation analysis on effects of child marriage

\begin{tabular}{l|l|l|l|l}
\hline $\mathbf{S} / \mathbf{N}$ & Effects of children marriage & Mean & SD & Decision \\
\hline 1 & $\begin{array}{l}\text { Young married girls may experience physical pain during sexual } \\
\text { intercourse due to immaturity of the sexual organs }\end{array}$ & 3.25 & .86 & Agreed \\
\hline 2 & $\begin{array}{l}\text { Some young married girls may develop obstetric fistula due to } \\
\text { prolonged delivery }\end{array}$ & 3.22 & 2.80 & Agreed \\
\hline 3 & Early marriage of girls could lead to their drop-out from school & 3.19 & .90 & Agreed \\
\hline 4 & Some girls who marry early may contact cervical cancer & 2.92 & .94 & Agreed \\
\hline 5 & $\begin{array}{l}\text { Child marriage could make girls to be poor due to limited } \\
\text { opportunities to work and earn income }\end{array}$ & 3.05 & .97 & Agreed \\
\hline 6 & $\begin{array}{l}\text { Child marriage can retard the economic development of a country } \\
\text { as the girls have little or nothing to contribute }\end{array}$ & 2.25 & .99 & Disagreed \\
\hline 7 & Early marriage violates women's right to freedom of education & 3.17 & .96 & Agreed \\
\hline 8 & Early marriage violates women's right to consensual marriage & 2.99 & .95 & Agreed \\
\hline 9 & $\begin{array}{l}\text { Girls who marry very early are not psychologically mature to } \\
\text { participate in decision making in their homes }\end{array}$ & 2.98 & .93 & Agreed \\
\hline 10 & $\begin{array}{l}\text { Young married girls are more prone to spousal abuse because of } \\
\text { difference in age, between them and their husband }\end{array}$ & 3.06 & .94 & Agreed \\
\hline
\end{tabular}

The investigation in table two has revealed that young married girls may experience physical pain during sexual intercourse due to immaturity of their sexual organs, with mean score of 3.25, some young married girls may develop obstetric fistula due to prolonged delivery, with mean score of 3.22, early marriage of girls could lead to their drop-out from school, with mean score of 3.19, some girls who marry early may contact cervical cancer, with mean score of 2.92 , child marriage could make girls to be poor due to limited opportunities to work and earn income with mean score of 3.05. The research also found out that early marriage violates women's right to freedom of education, with mean score of 3.17, early marriage violates women's right to consensual marriage, with mean score of 2.99 , girls who marry very early are not psychologically mature to participate in decision making in their homes, with mean score of 2.98 , young married girls are more prone to spousal abuse because of difference in age between them and their husband, with mean score of 3.06 and child marriage was found to promote illiteracy with mean score of 3.15. The mean scores of 3.25, 3.22, 3.19, 2.92, $3.05,3.17,2.99,2.98,3.06$ and 3.15 were all above the benchmark of 2.50 . The investigation has not revealed that child marriage can retard the economic development of a country as the girls have little or nothing to contribute, with mean score of 2.25 which is below the benchmark of 2.50 .

Hypothesis: There is no significant difference among the respondents in the urban, semi - urban and rural areas in their assessment of the effects of child marriage on the child.

Table 3. One way Analysis of Variance (ANOVA) of the difference among the respondents in the urban, semi - urban and rural areas in their assessment of the effects of child marriage on the child

\begin{tabular}{l|l|l|l|l|l|l}
\hline \multicolumn{1}{c|}{ Variables } & \multicolumn{1}{c|}{$\begin{array}{c}\text { Sum of } \\
\text { squares }\end{array}$} & Df & Mean square & F. critical & $\begin{array}{c}\text { Level of } \\
\text { sign. }\end{array}$ \\
\hline Between Groups & 3098.732 & & 1549.366 & & & \\
\hline within Groups & 5290.446 & 2 & 23.204 & 66.772 & 19.30 & 0.05 \\
\hline Total & 8389.177 & & & & & \\
\hline
\end{tabular}

Table 3 shows the value of F- calculated of 66.772, F critical value of 19.30, degree of freedom of 2 and level of significance of 0.05 . Since the value of $\mathrm{F}$-calculated of 66.772 is greater than $\mathrm{F}$ - critical value of 19.30 at 2 degree freedom and 0.05 level of significance, the hypothesis which says "there is no significant difference among the respondents in the urban, semi - urban and rural areas in their assessment of effects child marriage" is rejected. 


\section{Discussion}

The research has revealed that poverty of parents is a cause of child marriage with a mean score of 3.18 in table one, which is above the bench mark of 2.50. This implies that the poor economic condition of parents is a factor in child marriage. Parents who are living in abject poverty see the upbringing of their female daughters (in terms of provision for their basic needs) as a financial burden on the family, which may be relieved by early marriage of these children. This finding lays credence to Nour (2009) and Asad (2013) who asserted that some families view child marriage as a means of ensuring their daughters' financial security as well as reducing the economic burden of these children on the family.

Another finding of the research has indicated that protection of girls from sexual promiscuity is a cause of child marriage. This is illustrated with a mean score of 2.81. The notion that marriage offers girls a sense of protection from being sexually loosed has prompted parents to consent to early marriage of their daughters. This finding supports Nour (2006) who opined that parents feels that child marriage provides their daughters with a sense of protection from sexual promiscuity and safe from sexually transmitted infections. The investigation has revealed in table one that Islamic religion allows child marriage with mean score of 2.90. This finding agrees with UNICEF (2012) reports that the top five nations in the world with highest child marriage rates are Niger $75 \%$, Chad $72 \%$ Mali $71 \%$ Bangladesh $64 \%$ and Guinea $63 \%$. The five countries are Islamic majority. The research revealed in table one that high bride price encourages child marriage with mean score of 2.65. This finding gives support to Bearak (2006) and Nour (2006), who opined that in some countries, the younger the bride, the higher the pride price she may fetch. This practice according to Soraya (2006), Boyden (2012) and Showdhurry (2004), created an economic incentive where girls are sought and married early by their families to the highest bidder.

The research has found out that some young married girls may develop obstetric fistula due to prolonged delivery. The finding was in consonance with Nour (2006), when he maintained that teen pregnancy, particularly below age 15 increases risks of developing obstetric fistula, since their smaller pelvises make them prone to obstructed labour. The investigation found out in table two that early marriage of girls could lead to their drop-out from school with mean score of 3.19. This finding supports Lee, et al., (2012), when they stressed that early marriage impedes a girls' ability to continue her education as most of them drop-out of school following marriage. Another finding has indicated that early marriage violates women's right to freedom of education in table two with mean score of 3.17. This finding gives credence to UNICEF (2014), which opined that child marriage tends to violate women's rights such as equal access to education, freedom from violence and right to consensual marriage.

\section{Conclusion}

The conclusion drawn from the findings is that there is child marriage in Jigawa State, North-West Nigeria. Some of the causes of child marriage include poverty of parents, protection from sexual promiscuity, and high bride price. Other causes of child marriage are to prevent the girl from unwanted pregnancy, fear of the girl being a virgin and the Islamic religion that allows child marriage. Child marriage may have exposed some young married girls to experience obstetric fistula due to prolonged delivery, drop-out from school and violation of women's right to education and consensual marriage. Another effects of child marriage are, some girls who marry early may contact cervical cancer, young married girls may experience physical pain during sexual intercourse due to immaturity of the sexual organ and child marriage promotes illiteracy.

\section{Recommendations}

As a result of the findings and conclusion drawn, the investigator proposed the following recommendations:

1. The Jigawa State House of Assembly should enact a law that prohibits child marriage so that women's rights to freedom of education are not violated.

2. The government should organize public enlightenment campaigns to educate parents on the disadvantages of child marriage (such as drop- out of school) and advise them (parents) to shun child marriage so that their daughters can graduate from schools.

3. There should be a downward review of high pride price in Jigawa state to discourage parents from making their daughters go into early marriage.

4. Parents should avoid child marriage so that women's rights to consensual marriage are not violated.

5. Parents should not send their daughters on child marriage so that they do not face the danger of prolong delivery that could lead to development of obstetric fistula.

6. The government should provide economic opportunities for poor families so they can fend for their children (especially, their daughters) and thus curb child marriage. 
7. Non-governmental organizations should support girls' education through scholarship and also make provision for their basic needs in order to reduce financial burden on their parents. This will make parents desist from the practice of marrying their daughters off at an early age.

8. The International Day of the Girl child initiated by the United Nations General Assembly and celebrated October 11, every year should be taken more seriously by the Federal government and Jigawa State government. This avenue should be used to initiate programmes which stress on the ills of child marriage so as to eliminate it.

9. The Federal Government of Nigeria should implement the international Human Rights Convention Agreement on the Rights of the Child signed into law in 2003 as Children's Rights Act (CRA) and prosecute individuals who are working contrary to this legal documentation (especially in the aspect of child marriage).

\section{Counselling Implications}

The following are the counselling implications of the study:

1. Counsellors are to liaise with heads of various communities in Jigawa State in order to create a forum to educate parents on the associated risks of child marriage.

2. Counsellors are to collaborate with different ministries in charge of women affairs and organize sensitization programmes for parents on what child marriage entails, its consequences on the child, her family members and the government as well as the need to prevent it.

3. The Counselling Association of Nigeria (CASSON), Jigawa State chapter, should on a regular basis organize workshop, seminar and symposia for parents on the need to have equal regards for their children (males and females alike) and to change their perception of viewing their daughters as commodities that could be given off to the highest bidder.

4. The Councelling Association of Nigeria (CASSON) should work hand in hand with bodies such as Lagos State Women Affairs and Poverty Alleviation (WAPA), Lagos Education and Resource Network (LEARN), Lagos State Office of Public Defender so as to sensitize the public (especially parents) on the causes of child marriage and the devastating effects it (child marriage) has on girls' health, education economic, political and social lives. The sensitization campaign should be carried out in the six (6) Geo-political zones and the venue should be market places, town halls and primary schools.

5. The Counselling Association of Nigeria (CASSON) in collaboration with female Muslim legislators in the National Assembly in Nigeria should liaise with traditional rulers in different states of Nigeria to enlighten them on the gains that can accrue to girls, (their families and Nigeria as a country if offered opportunities to attain their educational aspirations.

\section{References}

"Q \& A" (2013). Child marriage and violations of girls rights to Human rights Watch (http://www.org.news).

Anita, R., Niranjan, S., Danielle, L., Donta, B., \& Jay, G. S. (2010). Adolescent marriage and marital violence among young adult women in India, International Journal of Gynecology \& obstetrics, 110(1), 35-39. https://doi.org/10.1016/j.ijgo.2010.01.022

Asad, Z. (2013). 42\% of Underage married girls from Pakistan. Express Tribune/ International Herald Tribune, New York Times.

Bearak, B. (2006). “The bride price”, (https:www.nytimes.com/2006/07/09/ magazine/09BRI.html) The New York Times.

Boyden, J. O., Pankhurst, A., \& Tafero, Y. (2012). Child protection and human traditional practices: female early marriage in Ethiopia. Development in practice, special issue: child protection in Development, 22(4), 510-522. https://doi.org/10.1080/09614524.2012.672957

Eradicating Child Marriage in Africa (2015). Forward UK-Forward, http.www.forwarduk.org.uk/key-issues/childmarriage forward UK retrieved in February 2015.

Gaffney-Rhys, R. (2011). International law as an instrument to combat child marriage. International Journal of Human Rights, 15(3), 359-373. https://doi.org/10.1080/13642980903315398

Lee-Rife, S., Malhotra, A., Warner, A., \& Glinski, A. M. (2012). What Works to prevent: Child Marriage: A Review of the evidence studies in family planning, 43(4), 287-303. https://doi.org/10.1111/j.1728-4465.2012.00327.x

Nour, N. (2006). Health Consequences of child marriage in Africa, Emerging infectious diseases, 12(11) 1644-1649. https://doi.org/10.3201/eid1211.060510 
Nour, N. M. (2006). "Health Consequences of child marriage in Africa" (http://www.cdc.gov/eid/article/12/11/0605770/article) Emerging Infectious Diseases, 12(11), 1644-1649.

Nour, N. M. (2009). Child Marriage is a silent health and human rights issue. Reviews in obstetrics and Gynaecology, 2(1), 51-56.

Ros, A. (2010). When the mother is a child: the impact of child marriage on the health and human rights of girls. Archives of disease in childhood, 95(1), 931-935. https://doi.org/10.1136/adc.2009.178707

Saudi Push to end Child marriage (2009). (https://www.thenatioanal.ae/ world/mena/Saudi-push-to-end-child-marriage 1541430.

Sheibu, I. I. (2012). Introduction to Applied Research and Econometrics: Benin City Nigeria: ACMP publishers.

Showdhury, F.D. (2004). The Social Cultural Context of Child Marriage in Baugladeshi village. International journal of social welfare, 13(3), 244-253. https://doi.org/10.1111/j.1369-6866.2004.00318.x

Soraya, J. (2006)., Modernity and early marriage in Iran. Journal of middle East Women studies, 2(1), 65-94. https://doi.org/10.2979/MEW.2006.2.1.65

UNFPA, Marrying too young: End Child marriage http://www.unfpa.org./sites/default/files/pubpdf/marrryingtooyoun.pdf

UNICEF (2012). A note on child marriage http://www.unicef.org/ policyanalysis/ files/noteonchildmarriage.pdf

UNICEF (2012). Child marriage is a death sentence for many young girls. http://www.unicef.org./sowc09/docs/sowco9countryexample-mali.pdf

UNICEF (2014). child marriage http://www.unicef.org/ protection/57929-58008.html

USA TODAY.COM (2009). 8 year old Saudi girl divorces 50 year old husband. http://usatoday30.usatoday.com/news/world/2009-04-30-saudi-arabian\&htm

\section{Copyrights}

Copyright for this article is retained by the author(s), with first publication rights granted to the journal.

This is an open-access article distributed under the terms and conditions of the Creative Commons Attribution license which permits unrestricted use, distribution, and reproduction in any medium, provided the original work is properly cited. 